\title{
DETERMINATION OF DEMAND FOR LAND CONSOLIDATION WORKS IN VILLAGES WITH A RIBBON LAND LAYOUT
}

\author{
Justyna Wójcik-Leń, Izabela Skrzypczak, Grzegorz Oleniacz, Karol Ożóg, \\ Przemysław Leń
}

\begin{abstract}
Summary
In the European Union, the restructuring of rural areas based on the consolidation process is a common activity, and therefore Poland's membership in the EU has enabled the development of these zones through financial support for the analysed activities. The development of agriculture in Poland, as well as its production capabilities, are spatially very diverse. One of the reasons for this is the process of long-term transformations of the agricultural economy in areas with a different socio-economic situation, lasting for many years. Land consolidation works are aimed at creating more favourable farming conditions in agriculture and forestry by improving the area structure of farms, forests and forest lands, rational land layout, adapting property borders to the land drainage system, roads and land relief. The research was carried out in the rural commune of Żarnów, located in the Opoczno poviat, in the Łódź voivodship, which included 41 registration precincts with a total area of $14,106.0$ hectares. In order to create a ranking of urgency of performed land consolidation and exchange works in the Żarnów commune, 32 most important factors characterizing individual villages were used previously. A ranking was made using the zero unitarisation and Hellwig's methods. The article is a continuation of research, where the authors identified spatial and technical parameters of agricultural land in the villages of Central Poland on the example of the examined commune.
\end{abstract}

\section{Keywords}

land consolidation $\bullet$ ranking methods $\bullet$ arable land $\bullet$ rural areas

\section{Introduction}

The reconstruction of the spatial structure of rural areas is necessary for sustainable development of these areas [Sobolewska-Mikulska and Stańczuk-Gałwiaczek 2018]. Land consolidation, which is a tool organizing the space, leads to the desired structural changes, but must be systematically implemented and become a permanent element of the long-term policy of voivodship self-governments in the field of arranging rural areas. Consolidating and exchange works should be carried out comprehensively, in 
conjunction with post-consolidation development. Only then can they serve the multifunctional development of rural areas. These works are effective tools for improving the identified defects, and also provide opportunities for alternative development of adverse, useless agricultural areas, the so-called problem areas of agriculture [Wójcik-Leń and Sobolewska-Mikulska 2017a, 2017b, Wójcik-Leń and Stręk 2017].

The problem of the unfavourable structure of arable land concerns many countries in Europe and the world. It results from historical, social or economic transformations that have often lasted for decades [Gonzalez et al. 2004, Cay et al. 2010, Pašakarnis and Maliene 2010, Hudecová 2016, Leń 2017, Stręk 2017, Kurowska and Kryszk 2017]. Land consolidation and exchange works are a tool enabling improvement of the spatial structure. Considering the fact that funds for the abovementioned activities are limited, it becomes necessary to select objects where these works should be carried out first. The current spatial structure of land in Poland is caused by such factors as: demographic relations, socio-economic and legal relations, marriage matching, and divisions of great landed properties before and after World War II, agriculture, regulation of farm ownership.

The purpose of this article is to determine the demand for land consolidation works in the municipality of Żarnów. The most important stage of the work was the creation of an urgency ranking for undertaking the consolidation and exchange works of lands in 41 villages of the examined commune, using methods of multivariate statistics. Studies have shown that the spatial structure in the Żarnów commune requires an improvement of a defective spatial structure. The conducted analyses showed that the methods of multivariate statistics used for research constitute a very good basis for establishing the urgency ranking of undertaking the consolidation and exchange works of land in the Żarnów commune.

\section{Location of the study area}

The commune of Żarnów is located in the Opoczno poviat, which is located in the south-eastern part of the Łódź voivodship. The commune's area is 14,106 ha, which is $13.56 \%$ of the total area of the Opoczno poviat and $0.77 \%$ of the area of the $\begin{gathered}\text { and } \\ \text { a }\end{gathered}$ voivodship. As shown in the Figure 1 below, the Żarnów commune is adjacent to the Paradyż commune from the north, and to the commune of Białaczów from the northeast. From the east it borders with the Końskie commune. The southwestern part of Żarnów borders with the Falków commune, while the southern border belongs to the Ruda Maleniecka commune. From the west, Żarnów is adjacent to the Aleksandrów commune. The Żarnów commune is divided into 30 village administrative units: Adamów (together with Malenie and Siedlów), Afryka, Antoniów, Bronów, Budków, Chełsty, Dąbie (including Ławki and Młynek), Dłużniewice, Grębenice, Jasion, Klew, Klew-Kolonia, Malków, Marcinków (with Kamieniec), Miedzna Murowana, Myślibórz (with Widuch), Nadole, Niemojowice, Paszkowice, Pilichowice, Ruszenice (with Ruszenice-Kolonia), Sielec (with Nowa Góra), Skórkowice (including Chorzew, Poręba and Skumros), Soczówki, Staszowa Wola, Topolice, Trojanowice, Wierzchowisko, Zdyszewice and Żarnów [Nawrocki 2000]. 


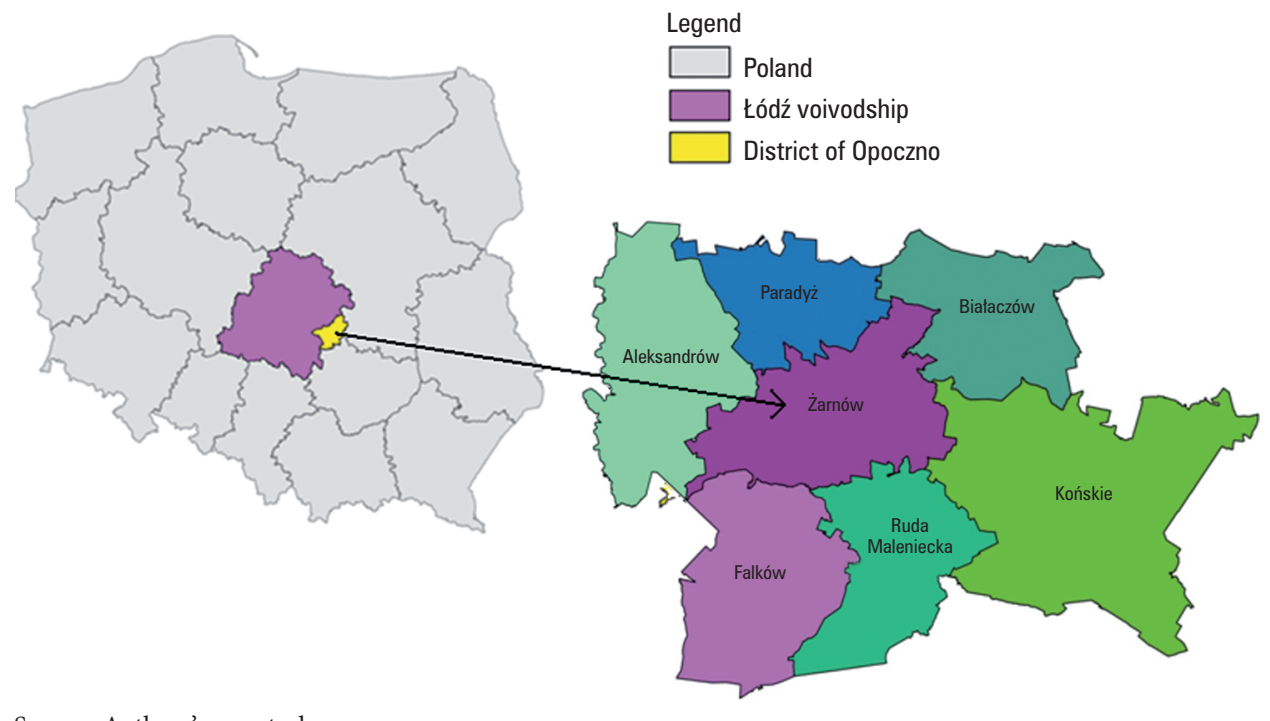

Source: Authors' own study

Fig. 1. Spatial distribution of the Żarnów commune on the map of Poland, the Łódź voivodship and the Opoczno poviat

\section{Methodology for developing the hierarchy of land consolidation works}

32 calculated factors characterizing the examined objects were used to rank the hierarchy of land consolidation works. The first group includes factors describing general information about the studied precincts in the commune, such as: $x_{1}$ - total area, $x_{2}-$ total number of plots, $x_{3}$ - number of inhabitants, $x_{4}$ - number of inhabitants per $\mathrm{km}^{2}$, $x_{5}-\%$ of the area of individual farms, $x_{6}-\%$ of the number of plots of individual farm lands, $x_{7}$ - average plot area (group 7). The second group consists of factors concerning individual farm lands such as: $x_{8}$ - number of registration units $7.1, x_{9}-\%$ of registration units 7.1, $x_{10}$ - number of plots of a registration unit 7.1, $x_{11}$ - area of plots of a registration unit 7.1, $x_{12}-\%$ of the number of plots 7.1 in relation to group $7, x_{13}-\%$ of the plot area in relation to group $7, x_{14}$ - average number of plots in a registration unit, $x_{15}$ - average area of a registration unit, $x_{16}$ - fragmentation index. The next group concerns the productivity index, which consists of the following factors: $x_{17}$ - of arable lands, $x_{18}$ - of grasslands. The fourth group belongs to factors concerning the ownership structure, in which we distinguish: $x_{19}-\%$ of land owned by the Agricultural Property Agency of State Treasury, group 1.1, $x_{20}$ - land owned by the communes. In the fifth group, regarding plots without road access, the following factors are included: $x_{21}-\%$ of the number of plots without road access, $x_{22}-\%$ of the plot area without road access. Group 6 consists of factors concerning the structure of land use, which includes the following factors: $x_{23}-\%$ of the share of orchards, $x_{24}-\%$ of the share of forests. The last group of factors is: $x_{25}-\%$ of the number of plots below the elongation index 


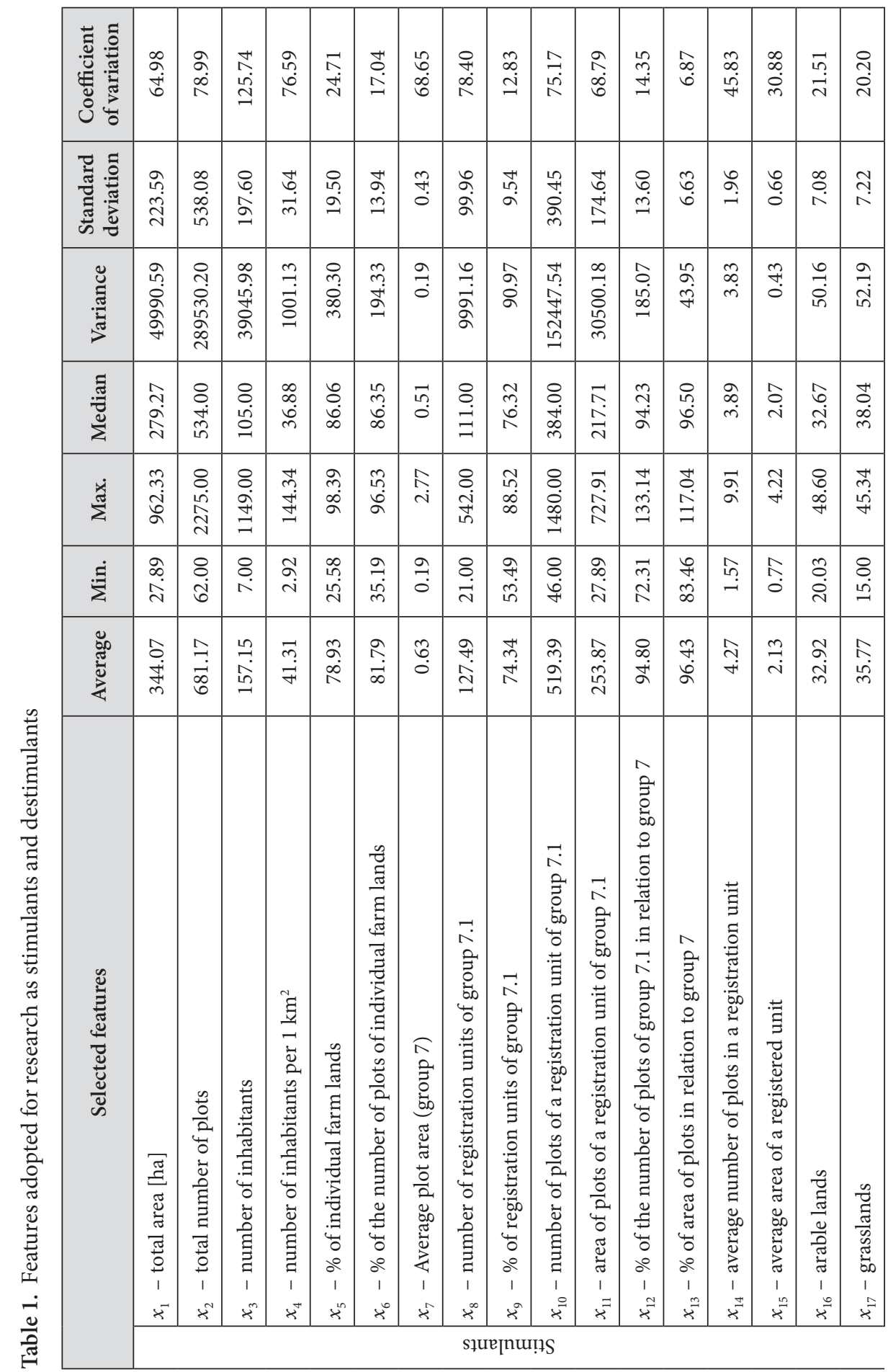




\begin{tabular}{|c|c|c|c|c|c|c|c|c|c|c|c|c|c|c|}
\hline$\stackrel{ }{\sigma}$ & $\begin{array}{l}\overrightarrow{7} \\
\dot{10} \\
\infty\end{array}$ & $\stackrel{\stackrel{一}{+}}{+\infty}$ & $\begin{array}{c}\vec{b} \\
\dot{0} \\
0\end{array}$ & $\begin{array}{l}2 \\
2 \\
\infty \\
0\end{array}$ & 命 & $\begin{array}{l}\stackrel{N}{\hat{q}} \\
\stackrel{+}{+}\end{array}$ & 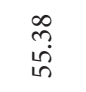 & 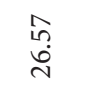 & $\begin{array}{l}\stackrel{N}{\hat{d}} \\
\text { d. }\end{array}$ & 岗 & $\begin{array}{l}\infty \\
\infty \\
\stackrel{\sim}{\sim}\end{array}$ & 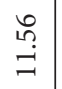 & $\begin{array}{l}\exists \\
\dot{0} \\
\sigma\end{array}$ & $\begin{array}{l}\stackrel{9}{1} \\
\text { న }\end{array}$ \\
\hline @ి & 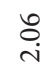 & $\stackrel{m}{\stackrel{m}{+}}$ & 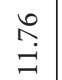 & $\stackrel{m}{\stackrel{\sim}{-}}$ & $\underset{ \pm}{\rightleftarrows}$ & $\begin{array}{l}\infty \\
\stackrel{0}{a}\end{array}$ & 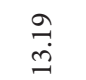 & $\stackrel{m}{+}$ & 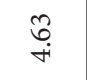 & $\begin{array}{l}\mathscr{L} \\
\infty \\
0 \\
0\end{array}$ & $\stackrel{\circ}{\stackrel{0}{0}}$ & 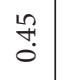 & $\begin{array}{l}\vec{\infty} \\
\dot{0}\end{array}$ & 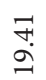 \\
\hline$\stackrel{\infty}{\stackrel{\infty}{\circ}}$ & $\stackrel{\overbrace{}}{+}$ & $\begin{array}{l}\tilde{n} \\
\stackrel{2}{a}\end{array}$ & $\begin{array}{l}\hat{n} \\
\infty \\
m \\
m\end{array}$ & $\begin{array}{l}\hat{\sigma} \\
\stackrel{\sigma}{\sigma}\end{array}$ & 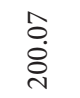 & 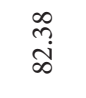 & 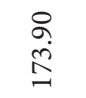 & $\vec{\Xi}$ & $\underset{\stackrel{+}{*}}{\stackrel{H}{*}}$ & $\stackrel{N}{\stackrel{N}{0}}$ & $\begin{array}{l}\infty \\
\stackrel{n}{n} \\
0\end{array}$ & 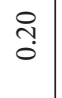 & $\begin{array}{l}\qquad n \\
0 \\
0\end{array}$ & $\begin{array}{l}\infty \\
\infty \\
0 \\
0 \\
m\end{array}$ \\
\hline în & $\stackrel{\text { S̆ }}{-}$ & $\begin{array}{l}\infty \\
\stackrel{0}{0} \\
\stackrel{9}{\sim}\end{array}$ & $\begin{array}{l}\grave{m} \\
\stackrel{0}{0}\end{array}$ & 옴 & 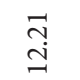 & $\begin{array}{l}\tilde{n} \\
\tilde{n}\end{array}$ & $\begin{array}{l}\stackrel{8}{\$} \\
\stackrel{+}{\sim}\end{array}$ & $\begin{array}{l}\text { స్ } \\
\text { }\end{array}$ & $\begin{array}{l}\stackrel{R}{0} \\
ٍ \\
0\end{array}$ & $\stackrel{\infty}{\stackrel{\infty}{+}}$ & $\begin{array}{l}\infty \\
\infty \\
i\end{array}$ & $\begin{array}{l}\stackrel{1}{m} \\
\dot{m}\end{array}$ & $\overrightarrow{\widehat{o}}$ & $\stackrel{\vec{n}}{\curvearrowright}$ \\
\hline$\stackrel{\text { mे }}{i}$ & $\begin{array}{l}\tilde{0} \\
\dot{0}\end{array}$ & $\begin{array}{l}2 \\
\infty \\
\infty \\
\infty\end{array}$ & $\begin{array}{l}\underset{H}{i} \\
\text { S }\end{array}$ & $\begin{array}{l}\infty \\
\infty \\
i n \\
n\end{array}$ & $\begin{array}{l}\text { ò } \\
\text { in }\end{array}$ & $\stackrel{7}{\dddot{a}}$ & $\frac{\partial}{\sigma}$ & $\begin{array}{l}\stackrel{+}{\infty} \\
\stackrel{+}{+}\end{array}$ & $\begin{array}{l}\text { fे } \\
\text { ॄे }\end{array}$ & $\stackrel{L}{\stackrel{\leftrightarrow}{+}}$ & $\begin{array}{l}\Delta \\
\text { in }\end{array}$ & $\underset{+}{\stackrel{+}{+}}$ & $\begin{array}{l}\stackrel{0}{n} \\
\dot{m}\end{array}$ & $\begin{array}{l}\infty \\
0 \\
\infty \\
\infty\end{array}$ \\
\hline$\stackrel{8}{\circ}$ & $\begin{array}{l}8 \\
0\end{array}$ & $\stackrel{\text { }}{-}$ & $\begin{array}{c}n \\
\tilde{0} \\
0\end{array}$ & $\stackrel{8}{\circ}$ & $\stackrel{8}{\circ}$ & $\begin{array}{l}\infty \\
\stackrel{\infty}{0}\end{array}$ & $\stackrel{\infty}{\stackrel{\infty}{i}}$ & กิ & 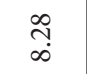 & 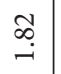 & $\stackrel{n}{\stackrel{n}{\sim}}$ & $\begin{array}{l}\tilde{b} \\
i\end{array}$ & $\begin{array}{l}8 \\
0 \\
0\end{array}$ & ঙ̊ \\
\hline 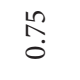 & $\underset{i}{\vec{i}}$ & $\begin{array}{l}\infty \\
\stackrel{0}{0} \\
ِ\end{array}$ & $\stackrel{n}{\hat{n}}=$ & $\begin{array}{l}\text { के } \\
\text { ᄋ्र }\end{array}$ & $\stackrel{\mathscr{n}}{\stackrel{n}{0}}$ & $\underset{\text { तે }}{\stackrel{\text { }}{ }}$ & $\begin{array}{l}\vec{\infty} \\
\stackrel{\sim}{ }\end{array}$ & $\begin{array}{l}\stackrel{0}{f} \\
\stackrel{6}{6}\end{array}$ & $\stackrel{m}{\stackrel{n}{\Omega}}$ & $\stackrel{m}{m}$ & 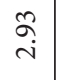 & $\begin{array}{l}\infty \\
\infty \\
\dot{m}\end{array}$ & 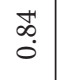 & $\begin{array}{l}\stackrel{\leftrightarrow}{+} \\
\stackrel{+}{+}\end{array}$ \\
\hline 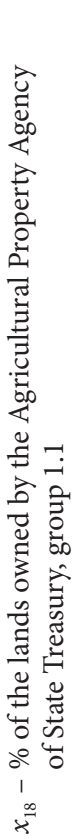 & 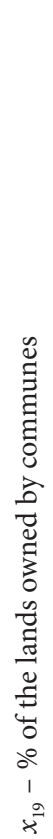 & 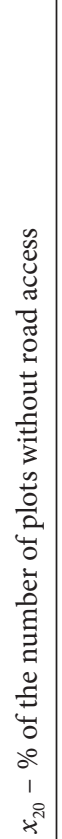 & 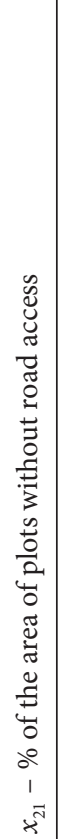 & 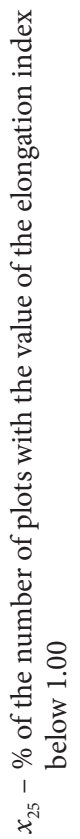 & 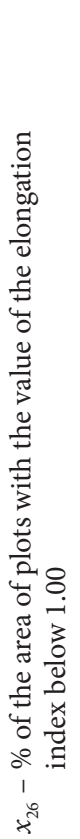 & 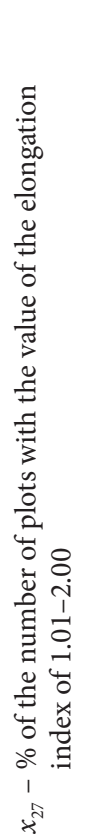 & 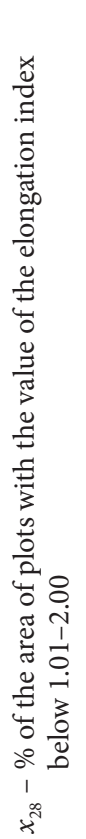 & 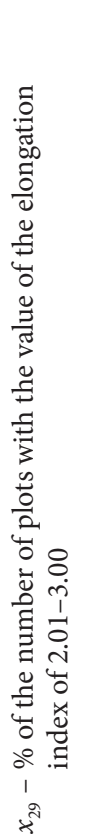 & 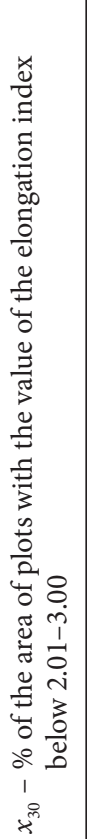 & 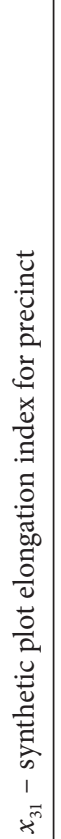 & 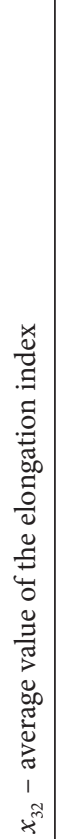 & 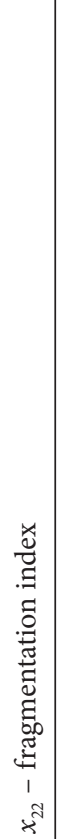 & 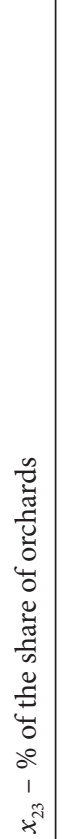 & 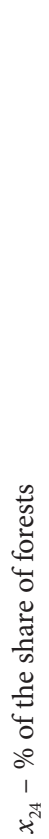 \\
\hline \multicolumn{10}{|c|}{ słue[nu!̣s } & \multicolumn{5}{|c|}{ słue[nuụısəa } \\
\hline
\end{tabular}


of $1.00, x_{26}-\%$ of the area of plots below the elongation index of $1.00, x_{27}-\%$ of the number of plots with the elongation index value of $1.01-2.00, x_{28}-\%$ of the area of plots with the elongation index of 1.01-2.00, $x_{29}-\%$ of the number of plots with the elongation index value of $2.01-3.00, x_{30}-\%$ of the area of plots with the elongation index value of 2.01-3.00, $x_{31}$ - synthetic plot elongation index for the precinct, $x_{32}$ - average value of the elongation index.

The initial analysis concerned the characteristics of the distribution values of individual variables presented in the form of descriptive statistics (Table 1). 27 factors were used as stimulants, while 5 factors were used as destimulants.

Before the synthetic ranking is prepared, a general selection is usually performed based on the diagnostic output values. A frequently used criterion excludes variables taken into account in the analysis whose coefficient of variation V is less than $20 \%$. Based on the factors examined, in terms of the coefficient of variation, the adopted criterion is not met by: \% of the number of plots of individual farm lands $(V=17.04)$, $\%$ of registration units of group $7.1(V=12.83)$, \% of the number of plots of group 7.1 in relation to group $7(V=14.35)$, \% of the plot area in relation to group $7(V=6.87)$, and the fragmentation index of the plots $(V=11.56)$. Despite this fact, it was decided to accept all variables regardless of their correlation level, due to the extreme importance of the analysed variables.

\section{Development of the demand ranking for land consolidation works}

The zero unitarisation method and the Hellwig's method were used to compile the urgency ranking of consolidation works and land exchange in the villages of the commune of Żarnów. These methods have measures that allow classification of objects by characteristics and subject matter of the examined object in terms of the analysis of spatial structure of lands carried out in the work [Jędrzejczyk et al. 2002].

The zero unitarisation method allows to order diagnostic variables characterizing the studied area. Diagnostic variables describing the examined object are divided into three groups [Leń and Mika 2016, Leń et al. 2016, Leń et al. 2017]:

1. Stimulants - variables whose increase in value causes an increase in assessment of characteristics of the examined object, then normalized variables are calculated according to the formula:

$$
Z=\frac{x-x_{\min }}{x_{\max }-x_{\min }}
$$

2. Destimulants - variables whose increase in value causes a decrease in assessment of characteristics of the examined object, then normalized variables are calculated according to the formula:

$$
Z=\frac{x_{\max }-x}{x_{\max }-x_{\min }}
$$


3. Nominates - variables that have the highest assessment (optimum) only for a certain value or range of values; as you move away from the optimum, the assessment of the phenomenon decreases, then normalized variables are calculated according to:

$$
\begin{aligned}
& Z=\frac{x-x_{\min }}{x_{\mathrm{opt}}-x_{\min }}, \text { for } x<x_{\mathrm{opt}} \\
& Z=\frac{x-x_{\max }}{x_{\mathrm{opt}}-x_{\max }}, \text { for } x>x_{\mathrm{opt}}
\end{aligned}
$$

where:

$Z$ - normalised variable,

$x$ - variable before normalization,

$x_{\max }$ - maximum value of the variable in a given set,

$x_{\min }-$ minimum value of the variable in a given set,

$x_{\mathrm{opt}}$ - optimal value of the variable in a given set.

The ordering of diagnostic features is the first step in order to obtain a multi-criteria assessment of each examined object. Thus, their total assessment is obtained by means of aggregation. The synthetic measure is obtained on the basis of the following formula [Pluta 1986], which is used to calculate average values of sets presenting individual features [Leń and Mika 2016, Leń et al. 2016, Leń et al. 2017].

$$
Z_{i}=\frac{1}{p} \sum_{j=1}^{P} X_{i j}(i=1, \ldots, m)
$$

Normalized measures are in the range $<0 ; 1>$. The results obtained can be interpreted as the average values of the optimal features of each object. It follows that the object's position in the ranking depends on the synthetic measure, which is higher the higher the position in the ranking.

The Hellwig's method sums up information from a number of diagnostic variables and assigns one measure to the analysed phenomenon. Identical groups of indicators were used to determine synthetic measures of the urgency of consolidation works in the study area. The following formula was used to calculate the examined indicator:

$$
W_{k}=\sum_{k=1}^{5}\left(C z n_{k} w_{k}\right)
$$

where:

$C z n_{k}$ is the normalization of features to simplify the comparison of values between departments, calculated from the formula:

$$
C z n_{k}\left(\frac{s_{j}}{s_{\max }}\right) k
$$

where:

$k$ is the next factor characterizing the analysed phenomenon $(k=1,2,3,4,5)$. 
The value of weighted average features $\left(s_{j}\right)$ in span ranges is calculated according to the formula:

where:

$$
s_{j}=\frac{1}{\sum w_{i}} \sum c_{i} w_{i}, j=(1,2,3,4)
$$

$c_{i}$ - the value of a particular feature in the $j$-th span range,

$w_{i}$ - the weight assigned to it.

As a result of calculations with the method of zero unitarisation and the Hellwig's method, for which the values of synthetic measures in the range $<0 ; 1>$ were obtained, the degree of the synthetic measure allowed to determine which precincts require the most urgent consolidation works. The consolidation works should be carried out first in the precincts shown in Table 2.

Table 2. Ranking of villages based on the calculated synthetic measure using the zero unitarisation and the Hellwig's methods

\begin{tabular}{|c|c|l|c|l|}
\hline \multirow{2}{*}{ Rank } & \multicolumn{2}{|c|}{ Zero unitarisation method } & \multicolumn{2}{c|}{ Hellwig's method } \\
\cline { 2 - 5 } & Synthetic meter & \multicolumn{1}{|c|}{ Precinct name } & Synthetic meter & Precinct name \\
\hline 1 & 0.542 & Soczówki & 0.960 & Żarnów \\
\hline 2 & 0.536 & Straszowa Wola & 0.652 & Topolice \\
\hline 3 & 0.528 & Żarnów & 0.647 & Pilichowice \\
\hline 4 & 0.519 & Wierzchowisko & 0.645 & Straszowa Wola \\
\hline 5 & 0.500 & Paszkowice & 0.636 & Wierzchowisko \\
\hline 6 & 0.498 & Jasion & 0.559 & Miedzna Murowana \\
\hline 7 & 0.490 & Malków & 0.517 & Soczówki \\
\hline 8 & 0.487 & Nadole & 0.507 & Nadole \\
\hline 9 & 0.486 & Pilichowice & 0.506 & Paszkowice \\
\hline 10 & 0.484 & Niemojowice & 0.498 & Niemojowice \\
\hline 11 & 0.484 & Topolice & 0.479 & Skórkowice \\
\hline 12 & 0.477 & Antoniów & 0.471 & Zdyszewice \\
\hline 13 & 0.444 & Trojanowice & 0.394 & Klew \\
\hline 14 & 0.444 & Kolonia Klew & 0.373 & Malków \\
\hline 15 & 0.436 & Klew & 0.362 & Myślibórz \\
\hline 16 & 0.433 & Skórkowice & 0.356 & Trojanowice \\
\hline
\end{tabular}




\begin{tabular}{|c|c|c|c|c|}
\hline 17 & 0.431 & Zdyszewice & 0.349 & Grębenice \\
\hline 18 & 0.423 & Miedzna Murowana & 0.346 & Młynek \\
\hline 19 & 0.420 & Ruszenice & 0.343 & Budków \\
\hline 20 & 0.418 & Poręba & 0.317 & Sielec \\
\hline 21 & 0.409 & Adamów & 0.307 & Adamów \\
\hline 22 & 0.404 & Budków & 0.286 & Ruszenice \\
\hline 23 & 0.401 & Marcinków & 0.286 & Jasion \\
\hline 24 & 0.400 & Kolonia Ruszenice & 0.282 & Marcinków \\
\hline 25 & 0.395 & Dąbie & 0.264 & Chełsty \\
\hline 26 & 0.384 & Młynek & 0.262 & Kolonia Klew \\
\hline 27 & 0.379 & Myślibórz & 0.249 & Bronów \\
\hline 28 & 0.369 & Tomaszów & 0.247 & Tomaszów \\
\hline 29 & 0.367 & Widuch & 0.243 & Antoniów \\
\hline 30 & 0.366 & Grębenice & 0.234 & Dłużniewice \\
\hline 31 & 0.362 & Afryka & 0.227 & Kolonia Ruszenice \\
\hline 32 & 0.356 & Skumros & 0.211 & Dąbie \\
\hline 33 & 0.356 & Maleni & 0.210 & Widuch \\
\hline 34 & 0.354 & Ławki & 0.186 & Kamieniec \\
\hline 35 & 0.343 & Nowa Góra & 0.185 & Afryka \\
\hline 36 & 0.333 & Chełsty & 0.182 & Ławki \\
\hline 37 & 0.329 & Bronów & 0.173 & Poręba \\
\hline 38 & 0.327 & Dłużniewice & 0.168 & Skumros \\
\hline 39 & 0.322 & Sielec & 0.156 & Nowa Góra \\
\hline 40 & 0.250 & Kamieniec & 0.156 & Siedlów \\
\hline 41 & 0.171 & Siedlów & 0.135 & Malenie \\
\hline
\end{tabular}

Source: own study based on the data form the Land and Property Register

According to the conducted research, the use of two separate methods allowed the separation of two different rankings of the urgency for consolidation works and exchange of lands. Four out of forty-one villages studied were in the same position in the ranking, constituting $10 \%$ of all villages. The difference of one place in the examined rankings by two methods covers 3 precincts, which constitute $7 \%$ of the entire analysed commune. Four villages differ by 2 places in the ranking. The next 3 villages 


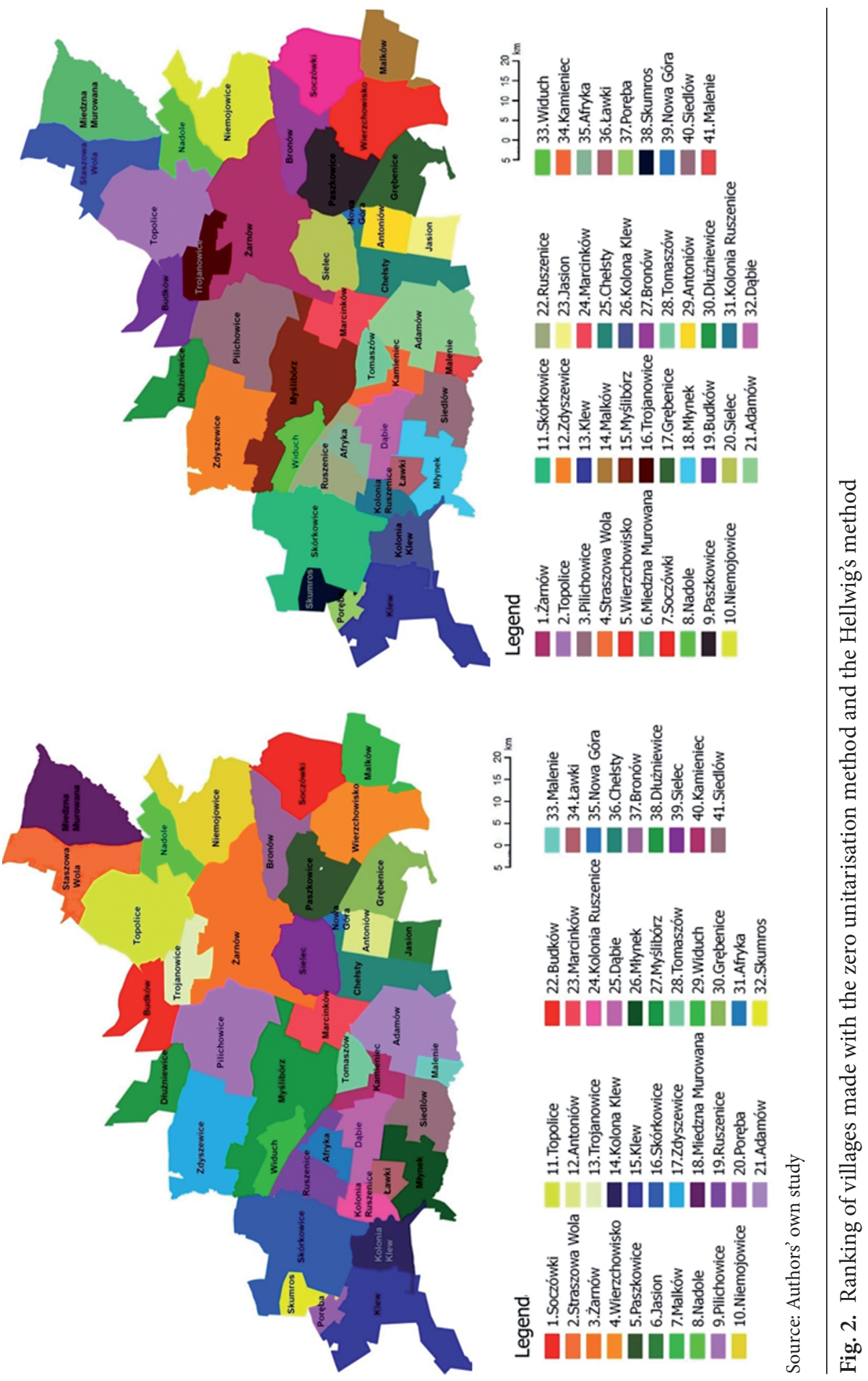


converge in the rankings by 3 places. In terms of difference of 4 places, there are 4 villages, which is $10 \%$ of the whole commune. The next two villages differ by 5 places in the analysed rankings. Four villages shifted 6 places in the ranking. The remaining 17 villages are distinguished by $7,8,9,10,11,12,13,17$ and 19 places in the ranking. The biggest difference in the synthetic measure is for Sielec, which moved 19 places in the compared rankings for both methods.

As a result of the ranking analysis (Table 2, Fig. 2), it should be stated that the consolidation works should be carried out first in the villages of Adamów, Nadole, Niemojowice and Tomaszów. The surveyed precincts are characterized by a relatively large percentage of plots in the individual sector in relation to the total number of plots, namely: Adamów (87\%), Nadole (81\%), Niemojowice (85\%), and a much smaller one for the village of Tomaszów (39\%). In Adamów, Nadole and Tomaszów, over 34\% of the plots have no road access.

In terms of the largest average plot area in the individual sector, Adamów stands out, with an average area of 1.0507 ha for 442 plots. Whereas the smallest average plot area in the individual sector falls to the village of Nadole -0.1878 ha, where there are 1013 plots.

The analysis showed that the results obtained are the basis for determining the order of consolidation works and land exchange in the examined commune.

\section{Summary}

The Łódź voivodship is characterized by worse than average conditions for the development of agriculture in the country, but at the same time this form of activity is, next to industry, the main economic specialization of the region. Small and very small farms with low productivity dominate in the discussed voivodship. Rural areas are characterized by insufficient economic activity and poor social activation, an unfavourable situation in terms of equipping with network devices or difficult access to social services. That is why the restructuring of agricultural production and raising its qualitative values aiming at increasing economic efficiency as well as improving the living conditions of the inhabitants is so important for rural areas. The specificity of agricultural farms in the Łódź voivodship and environmental conditions point to the possibility of building a strong agricultural sector oriented towards eco-farming, which will improve the ecological situation of the voivodship.

The reconstruction of the agrarian structure of rural areas is necessary for the sustainable and balanced development of these areas. Land consolidation, which is a tool organizing the space, leads to the desired structural changes, but must be systematically implemented and become a permanent element of the long-term policy of voivodship self-governments in the field of arranging rural areas.

Studies have shown that the spatial structure in the Żarnów commune requires an improvement of a defective spatial structure. This applies to both the removal of small and narrow plots and the improvement of road network infrastructure. Therefore, it is necessary to carry out the process of land consolidation and exchange in this area. The 
conducted analyses showed that the methods of multivariate statistics used for research constitute a very good basis for establishing the urgency ranking of undertaking the consolidation and exchange works of land in the Żarnów commune. The consolidation and exchange of lands throughout the entire area under study in the same time is impossible, which is why the work order specified in the paper is a very important determinant for creating a new spatial order and improving agriculture in the Żarnów commune.

\section{References}

Cay T., Ayten T., Iscan F. 2010. Effects of different land reallocation models on the success of land consolidation projects: Social and economic approaches. Land Use Policy, 27(2), 262-269.

Gonzalez X.P., Alvarez C.J., Crecente R. 2004. Evaluation of land distributions with joint regard to plot size and shape. Agricultural Systems. https://doi.org/10.1016/j.agsy.2003.10.009

Hudecová L., Geisse R., Vardžáková M., Turan P. 2016. Calculation of land fragmentation. Kartografické listy (Cartographic letters), 24(1), 12-22.

Jędrzejczyk Z., Kukuła K., Skrzypek J., Walkosz A. 2002. Badania operacyjne w przykładach i zadaniach, Wydawnictwo Naukowe PWN, Warszawa.

Kurowska K., Kryszk H. 2017. Legal and market-related conditions underlying management of state treasury agricultural real estate in Poland. Engineering for Rural Development, 16, 1093-1099.

Len P., Oleniacz G., Skrzypczak I., Mika M. 2016. The Hellwig's and zero unitarisation methods in creating a ranking of the urgency of land consolidation and land exchange work. 16th International Multidisciplinary Scientific GeoConference SGEM 2016. www.sgem.org, SGEM2016 Conference Proceedings, June 28-July 6, vol. 2, 617-624.

Leń P. 2017. The ranking destination areas for land consolidation works, due to the size checkerboard land on the example of Białaczów. "Environmental Engineering" 10th International Conference, Vilnius, Gediminas Technical University. DOI: https://doi.org/10.3846/enviro.2017.212.

Leń P., Mika M. 2016 Ranking przeznaczenia obszarów do prac scaleniowych ze względu na rozmiary szachownicy gruntów, na przykładzie gminy Sławno. Infrastruktura i Ekologia Terenów Wiejskich, II. PAN, Kraków, 290-296.

Leń P., Oleniacz G., Skrzypczak I., Mika M. 2017. Methodology for assessing the size and liquidation of the outer patchwork of land. World Multidisciplinary Earth Sciences Symposium (WMESS 2017). IOP Conf. Series: Earth and Environmental Science, 95032020. DOI:10.1088/1755-1315/95/3/032020.

Pašakarnis G., Maliene V. 2010. Towards sustainable rural development in Central and Eastern Europe: Applying land consolidation. Land Use Policy, 27(2), 545-549. https://doi. org/10.1016/j.landusepol.2009.07.008.

Sobolewska-Mikulska K., Stańczuk-Gałwiaczek M. 2018. The assessment of the scope of implementation of the idea of multifunctional rural development in land consolidation projects in Poland. Journal of Agribusiness and Rural Development, 1(47), 81-88.

Strek Z. 2017. Engineering for rural development analysis of demand for land consolidation in Milejów commune, Łęczna district. Engineering for Rural Development, Jelgava, 2426.05.2017, 593-599.

Wójcik-Leń J., Stręk Ż. 2017. Proposal for land consolidation project solutions for selected problem areas. World Multidisciplinary Earth Sciences Symposium (WMESS 2017). Earth and Environmental Science, 95, 032016. DOI :10.1088/1755-1315/95/3/032016. 
Wójcik-Leń J., Sobolewska-Mikulska K. 2017a. Specific features of development of selected agricultural problematic areas in the land consolidation process. Journal of Water and Land Development, 34, 249-258. DOI: 10.1515/jwld-2017-0060.

Wójcik-Leń J., Sobolewska-Mikulska K. 2017b. Issues related to marginal lands with reference to selected agricultural problematic areas. Journal of Water and Land Development, 35, 265273. DOI: 10.1515/jwld-2017-0093.

Dr inż. Justyna Wójcik-Leń Uniwersytet Przyrodniczy w Lublinie Katedra Inżynierii Środowiska i Geodezji e-mail: justyna.wojcik-len@up.lublin.pl

ORCID: https://orcid.org/0000-0002-1130-9156

Dr hab. inż. Izabela Skrzypczak, prof. PRz

Politechnika Rzeszowska

Katedra Geodezji i Geotechniki

ul. Poznańska 2, 35-959 Rzeszów

e-mail: izas@prz.edu.pl

ORCID: https://orcid.org/0000-0003-0978-3040

Dr inż. Grzegorz Oleniacz, prof. PRz

Politechnika Rzeszowska

Katedra Geodezji i Geotechniki im. Kaspra Weigla

ul. Poznańska 2, 35-959 Rzeszów

e-mail: oleniacz@prz.edu.pl

ORCID: https://orcid.org/0000-0003-3318-0928

Mgr inż. Karol Ożóg

Biuro Gospodarki Mieniem Miasta Rzeszowa

Plac Ofiar Getta, 35-002 Rzeszów

e-mail: karol.ozog@gamil.com

ORCID: https://orcid.org/0000-0002-2464-9010

Dr hab. inż. Przemysław Leń, prof. UP

Uniwersytet Przyrodniczy w Lublinie

Katedra Inżynierii Środowiska i Geodezji

ul. Akademicka 13, 20-950 Lublin

e-mail: przemyslaw.len@up.lublin.pl

ORCID: https://orcid.org/0000-0003-0810-9986 